\title{
(POSTER) Citizens Energy Group: Mobile Water Distribution System for Providing Water and Reducing Plastic Waste
}

\author{
Alex Pruitt \\ University of Indianapolis, pruitta@uindy.edu \\ Alysa Epperson \\ University of Indianapolis, eppersona@uindy.edu \\ Jonathen Key \\ University of Indianapolis, keyj@uindy.edu \\ Victor Antoñon Rodriguez \\ University of Indianapolis, antononrodriguezv@uindy.edu \\ Paul Talega \\ University of Indianapolis, talegap@uindy.edu \\ See next page for additional authors
}

Follow this and additional works at: https://docs.lib.purdue.edu/aseeil-insectionconference

Part of the Engineering Education Commons, Mechanical Engineering Commons, and the Other Engineering Commons

Pruitt, Alex; Epperson, Alysa; Key, Jonathen; Antoñon Rodriguez, Victor; Talega, Paul; Ricco, George; dharmarathne, Suranga; Olawale, David; Saqib, Najmus; and Emery, James, "(POSTER) Citizens Energy Group: Mobile Water Distribution System for Providing Water and Reducing Plastic Waste" (2019). ASEE IL-IN Section Conference. 3.

https://docs.lib.purdue.edu/aseeil-insectionconference/2019/posters/3 
Presenter Information

Alex Pruitt, Alysa Epperson, Jonathen Key, Victor Antoñon Rodriguez, Paul Talega, George Ricco, Suranga dharmarathne, David Olawale, Najmus Saqib, and James Emery 


\section{Introduction and Overview}

Citizens Energy Group tasked our team of four to construct a mobile water distribution unit that promotes environmental stewardship and educational community engagement opportunities. This Project will also benefit users by providing potable drinking water and conservation of single use plastic water bottles.

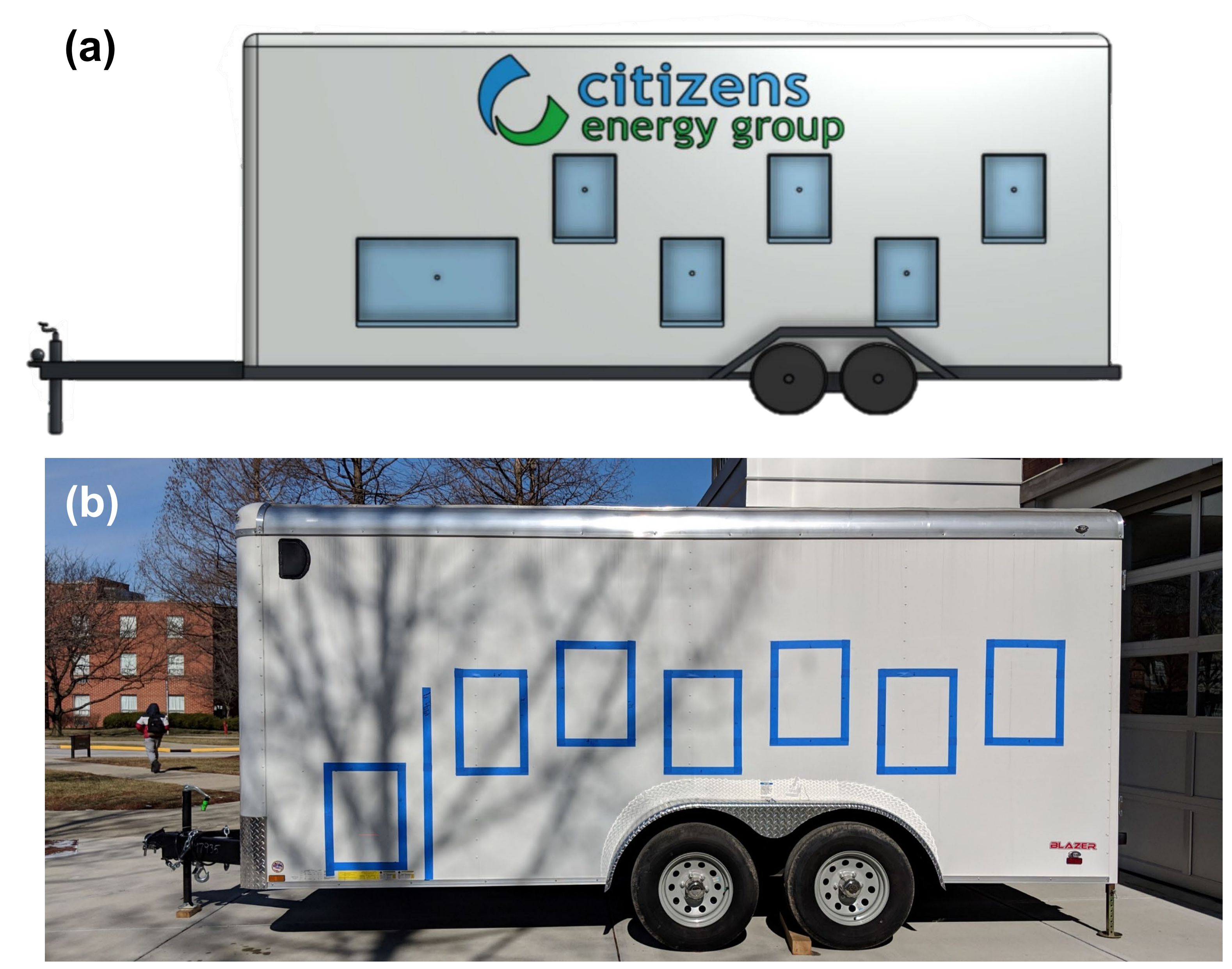

Fig. 1. (a) Initial CAD drawing, and design of housing and trailer system. (b) Layout of 7 of 11 distribution stations (blue rectangles) according to initial CAD drawing.

\section{Fabricated system}

For this project we fabricated housing, distribution, and cooling systems. To create the housing system, we cut into a trailer and installed recessed water distribution stations. The distribution stations are fabricated with stainless steel to limit the risk of oxidation from exposure to the elements.

Acknowledgements: We would Like to thank our business client, Citizen's Energy Group, and Dr. Jose Sánchez (Program Advisor), and would also like to thank the R.B. Annis School of Engineering for financial support of this project.
The distribution system uses a pump and two 275 gallon tanks. The trailer will also be equipped to connect to a fire hydrant for continuous filling of the tanks. For the cooling system, we assembled copper pipes in a cooler. In this cooler, ice will be added so that the water can cool from $90^{\circ} \mathrm{F}$ to $60^{\circ} \mathrm{F}$.

\section{Testing}

The cooling system is currently in its third version. Due to multiple failures for the first version (Fig. 2(a)), and later the second version, changes were made to the length of the copper tubing in use. The distribution station designs are in version two. During the proof of concept, there were concerns about the ease of fabrication. The distribution station design has now been simplified to accommodate that need. At this time, final testing has not begun. Our team has plans to test (i) the cooling system, Temperature must drop from $90^{\circ} \mathrm{F}$ to $60^{\circ} \mathrm{F}$; (ii) the plumbing system: test for leaks at high pressures; and (iii) the flow rate from spigots, a single distribution station must fill one bottle in 10 seconds or less.
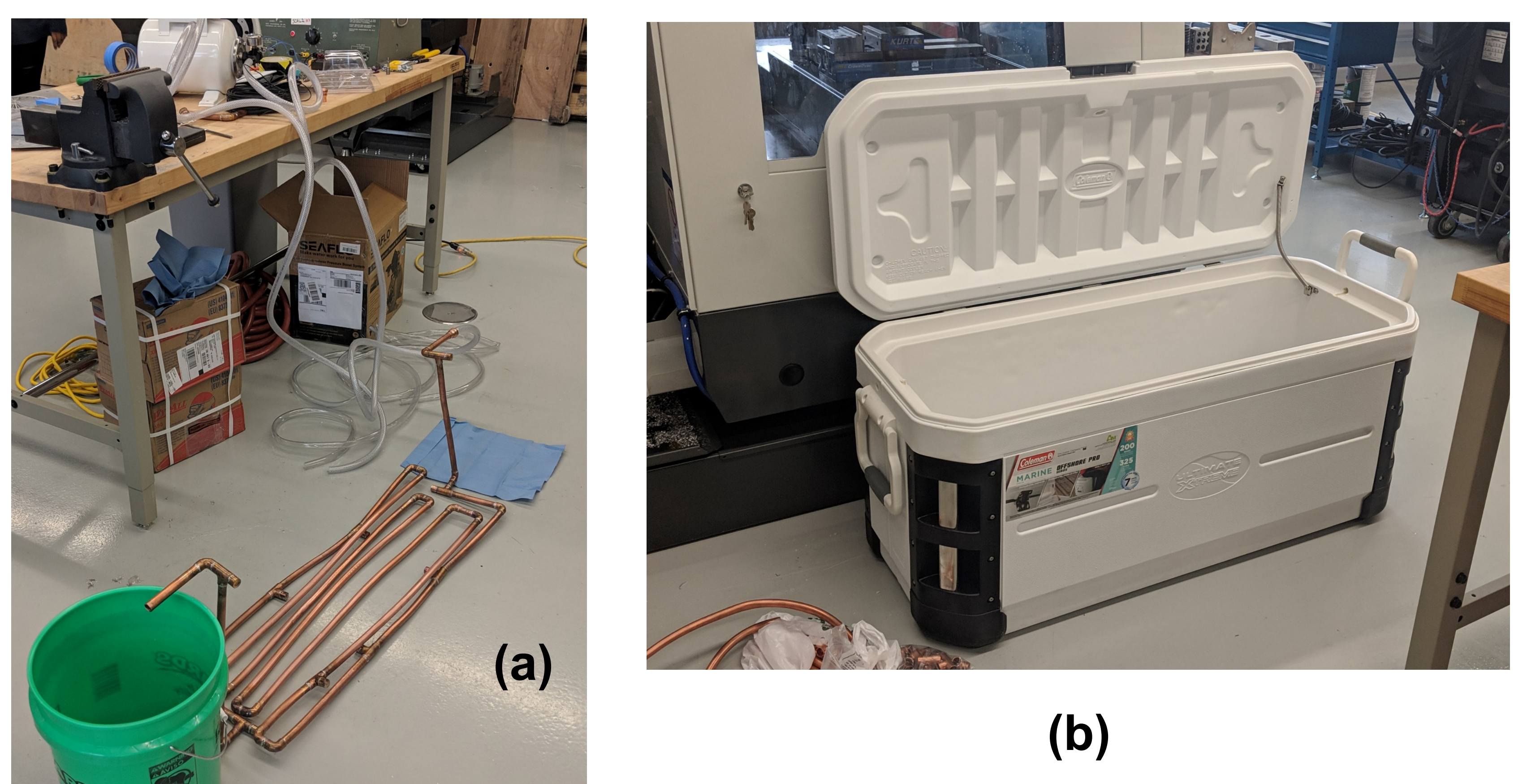

(b)

Fig. 2. (a) Demonstration of pressure testing for cooling system. (b) Copper pipes are laid in cooler shown, with ice to complete cooling system.

\section{Optimization of Design}

We designed the device to meet our customer requirements. First, it should be safe and under $\$ 10,000$. To save money, we purchased a pre-built $7^{\prime} \times 16^{\prime}$ trailer, with a side and back door for ease of access. On this trailer, there are a total of 11 approved distribution stations. The water wagon should be educational, in that it will teach customers the importance of keeping a clean environment and limiting plastic waste. The device should me mobile. This trailer has a double-axle to increase weight capacity, and does not require a special license to drive. Finally, it should be marketable, and to meet that, the trailer will be wrapped with the Citizens Energy Group logo, and will have customized drain covers as displayed in Fig. 3(a). (a)

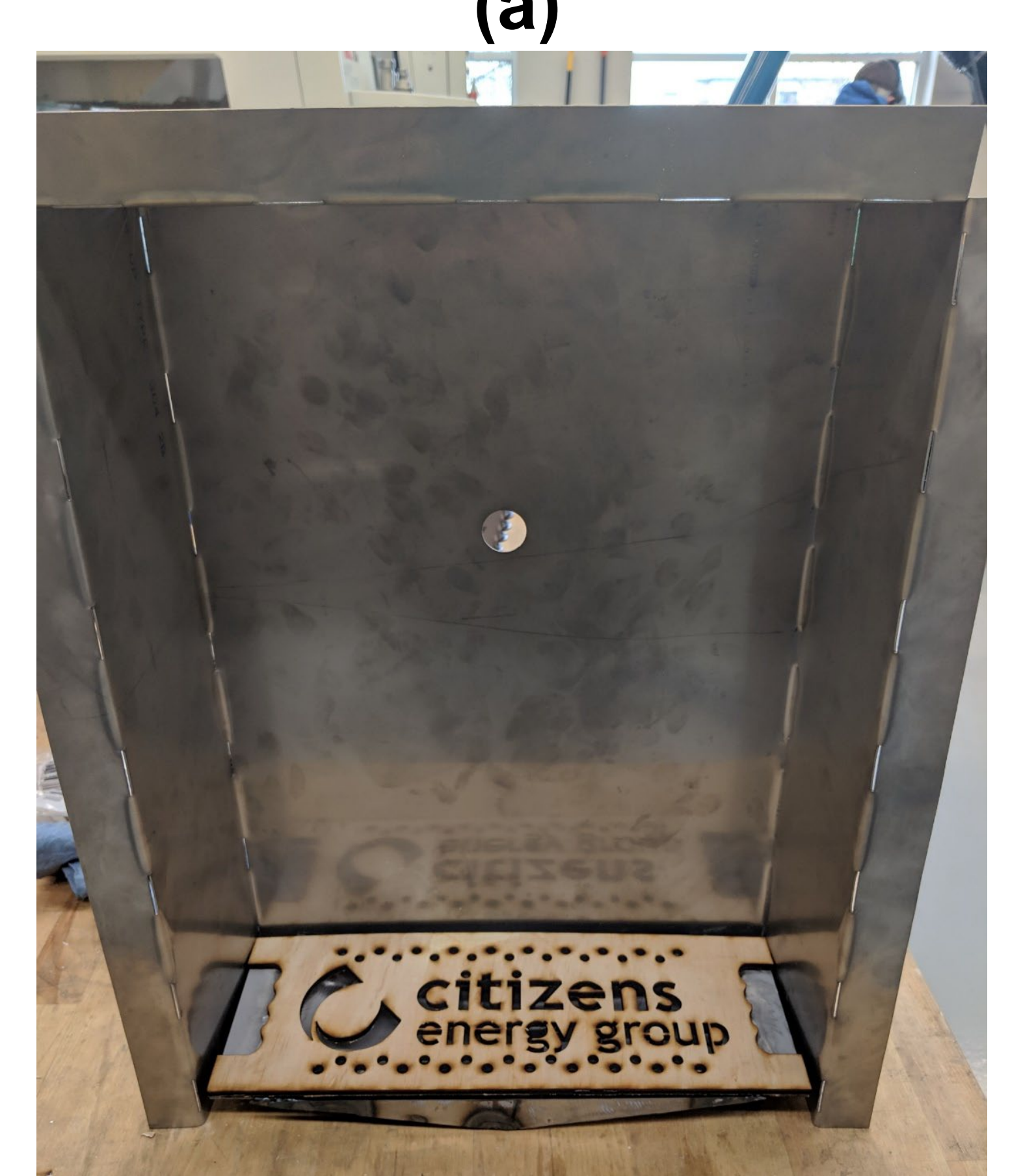

(b)

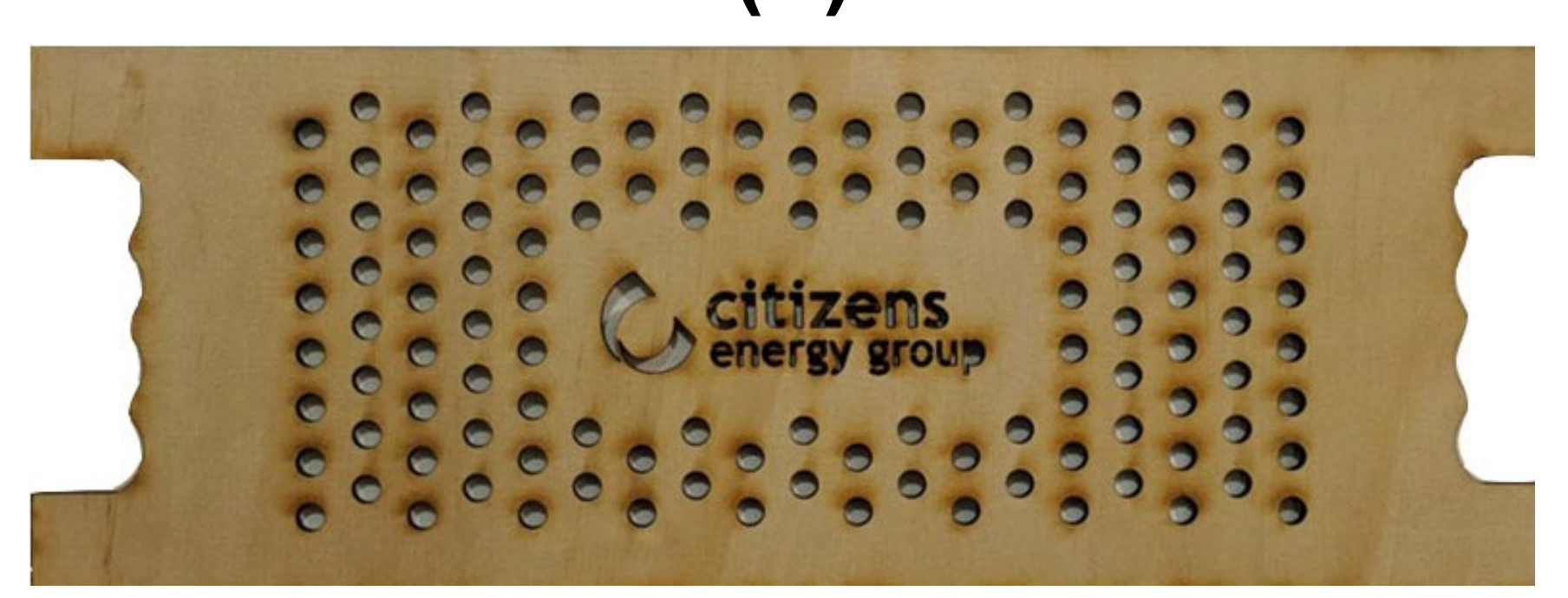
distribution station. Version 1: stainless steel housing, attached drain, removable, customizable drain cover. (b) Version one of the customizable drain cover.
Fig. 3. (a) Proof of concept for

\section{Conclusion and Future Work}

We are fabricating a safe, educational, and mobile water distribution unit within a budget of $\$ 10,000$. Future steps will include both fabrication and testing. We will work on the distribution stations by riveting stainless sheets. For the plumbing, we will run pipes from the tanks, through cooling and to distribution stations, checking both leaks and flow rates. For the cooling system we will test cooling from an extreme temperature, $90^{\circ} \mathrm{F}$ to an ideal temperature of $60^{\circ} \mathrm{F}$. 